\title{
Evaluation of the effectiveness of the fungicidal effect of drugs against pathogens of cultivated grapes (Vitis vinifera L.)
}

\author{
Adelya Rakhmaeva ${ }^{1}$, Evgeny Nikitin ${ }^{1}$, Dmitry Terenzhev $^{1}$, Natalia Sharonova ${ }^{1}$, and \\ Magomedsaygid Beybulatov ${ }^{2}$ \\ ${ }^{1}$ Federal State Budgetary Institution of Science "Federal Research Center "Kazan Scientific Center of \\ the Russian Academy of Sciences", 420111, Tatarstan, Kazan, Lobachevsky str., 2/31, a/ya 261, \\ Russian Federation \\ ${ }^{2}$ Federal State Budgetary Institution of Science All-Russian National Scientific Research Institute of \\ Vineyards and Wine MAHARACH RAS, 298600, Yalta, str. Kirova, 31, Republic of Crimea
}

\begin{abstract}
The Vitis vinifera $\mathrm{L}$. cultural grape includes many varieties that are highly valued in winemaking and viticulture, as raw materials for the production of fresh and dried berries, for the production of wines. The fruits of cultural grapes play an important role in medicine, where they are used as a source of substances with high antioxidant activity. Grapes are often affected by phytopathogenic fungal infections. In recent years, a large number of reports have appeared in the literature about the acquisition of resistance of microorganisms to industrial pesticide preparations, which in turn leads to an increase in drug doses, the multiplicity of treatments and the accumulation of harmful substances in the environment and in the plants themselves. In this study, we evaluate the effectiveness of the fungicidal action of industrial preparations and plant extracts in relation to two native species of fungi (V1 and V2) isolated from the leaves of cultivated Vitis vinifera L. grapes, as well as against the phytopathogen Alternaria solani K-100054. Minimal inhibitory (MIC) and fungicidal concentrations (MFC) were detected for each sample. Ethanol extracts of plants showed low antimycotic activity in relation to fungi cultures isolated from grapes. Activity started from $0.0625 \%$. The best result among industrial fungicides was shown by the drug "Maxim", whose MIC values was $0.097 \mu \mathrm{g} / \mathrm{mL}$, and the MFC varies between 3.125-12.5 $\mu \mathrm{g} / \mathrm{mL}$ for pathogens $\mathrm{V} 1$ and $\mathrm{V} 2$, respectively.
\end{abstract}

\section{Introduction}

According to the International Organization of Grapes and Wine, about 77.8 million tons of grapes are produced per year, of which $57 \%$ are wine grapes, $36 \%$ are table grapes and $7 \%$ are dried grapes [1]. In the fruits of the grape Vitis vinifera L. a high content of phenolic compounds was found, among which the main classes were flavonoids, phenolic acids, other polyphenols, lignans and stilbens. The most common compounds are myricetin 3-Oglucoside and quercetin 3-O-glucoside. Isomeric forms of ferulic acid, vanillic acid, epigallocatechin, kaempferol and pyrogallol were also found [2]. The grapes contain caffeic 
acid, which has a wide range of pharmaceutical effects, including antitumor, antithrombotic, hypotensive, antifibrotic and antiviral effects [3]. Gentisic acid has antioxidant and anti-inflammatory effects, as well as being able to improve cardiovascular problems associated with aging, such as hypertension, atherosclerosis and dyslipidemia. [4]. Extracts of Vitis vinifera L. leaves they exhibit antioxidant activity and protection against DNA damage, and an antimutagenic effect [5]. Vine leaves are part of the traditional Serbian diet [6].

The incidence of fungal infections is one of the main causes of economic losses recorded in the viticulture sector [7]. Most cultivated vineyards are susceptible to various diseases, such as false powdery mildew (Plasmopara viticola (Berk. \& MA Curtis) Berl. \& De), anthracnose (Elsinoe ampelina Shear), isariopsis leaf spot (Pseudocercospora vitis (Lév.) Speg.), gray rot (Botrytis cinerea Pers) and ripe rot (Glomerella cingulata (Stoneman) Spauld \& Schrenk). Thus, methods of combating these diseases are necessary and of particular importance, because they must be effective and efficient and must lead to a competitive cost of production in the market [8].

Currently, the fight against grape diseases is based on two main methods: the use of resistant varieties and the use of fungicides. Commercial varieties and breeding lines with resistance to certain diseases are available for some crops [9, 10]. However, the rapid development of new resistant strains of pathogens hinders the fight against these diseases through the selection of resistant varieties and the use of traditional pesticide preparations $[11,12]$. The decline in the effectiveness of commercial drugs increases the need for alternative methods of disease control.

Food safety is one of the main problems associated with fresh fruits and vegetables. According to the World Health Organization (WHO), millions of people associated with agriculture suffer from severe pesticide toxicity, and about 18,000 people die every year [13]. Safer alternatives to chemicals are currently available, including inorganic, organic and biological controls [14]. Currently, numerous studies are being conducted in the field of biological protection of plants that would not have a negative impact on the environment and would not contain dangerous chemicals $[15,16]$. There are a large number of plants that have antimicrobial agents and antioxidants in their composition [17]. Natural products, such as plant extracts, can be an alternative to synthetic fungicide.

\section{Materials and methods}

Samples of the Vitis vinifera L. vine collected in the southern zone of Crimea in one of the branches of the Massandra farm in early April 2021 and provided to us by specialists of the All-Russian National Scientific Research Institute of Vineyards and Wine MAHARACH RAS. From the vine, presumably affected by oidium, 2 types of fungi (V1 and V2) were isolated. The pathogen was isolated on a dense nutrient medium of Chapek, followed by the separation of fungal pathogens from accompanying bacterial colonies, the growth of a pure culture on the medium of potato-glucose agar.

The subject of the research were ethanol extracts of plants of dried marsh cudweed (Gnaphalium uliginosum L.); common juniper (Juniperus communis L.); dwarf everlast (Helichrysum arenarium (L.) Moench); Siberian carpet cypress (Microbiota decussata Kom.), Persian cornflower (Centaurea dealbata Willd.), mountain cornflower (Centaurea montana L.) and bighead knapweed (Centaurea macrocephala Muss.Puschk. ex Willd.). Dried plants were ground into a powder with a particle size of $0.2-0.5 \mathrm{~mm}$ in a laboratory mill (LM 202, Russia) and extracted by maceration [17, 18]. The powder (20 g) was extracted using $70 \%$ ethanol, using a ratio of dry weight to solvent (1:8); then the mass was 
stirred at $45{ }^{\circ} \mathrm{C}$ for 1.5 hours at $500 \mathrm{rpm}$ using a magnetic stirrer (IKARCT basic). The resulting mass was centrifuged and filtered, and concentrated on a rotary evaporator (Labtex Re 100-Pro, Russia) in a water bath at a temperature of $35-37^{\circ} \mathrm{C}$. The extracts were stored in a freezer at $-35^{\circ} \mathrm{C}$ for further analysis. To analyze for fungicidal activity, the dried extracts were re-dissolved in dimethyl sulfoxide (DMSO) [18, 19].

Industrial fungicidal preparations were taken as objects of research: "Maxim", "Skor", "RidomilGold MZ-profi" (Syngenta); "Karamba", "Premis 200", "Strobi" (BASF AgriProduction SAS); "Phytolecary" (Jiangsu Agrochem Laboratory Co. Ltd.), "Universal" (Sunrise Chemicals Co. Ltd.); "Abiga Peak" (LLC "Agricultural Chemistry"). Fungicidal drugs to increase the solubility of drugs, DMSO was used instead of water. The initial concentrations of the samples were calculated by dry matter - for extracts and by the content of the active substance - in fungicidal preparations. The fungistatic activity of the ethanol extract was measured by serial dilution [20] in a liquid medium of potato-glucose broth. A piece of fungi mycelium was placed in each tube with an extract of a known concentration. After incubation, the vital activity of microorganisms was assessed visually and a minimum concentration was established, contributing to the cessation of culture growth, without its death (minimum inhibitory concentration MIC). To determine the minimum fungicidal concentrations of the extract, pieces of mycelium of fungi taken from all test tubes without visible growth were added to Petri dishes with agarized KGA nutrient medium using a bacteriological loop. The minimum concentration at which the death of fungi occurred was considered the minimum fungicidal concentration (MFC). Test tubes containing only nutrient media were used as a control. Incubation of the analyzed samples was carried out in a thermostat at $26^{\circ} \mathrm{C}$ for 7 days. The growth of microorganisms was determined visually. All analyses were performed in three repetitions [19]. An identical technique was used to evaluate the effectiveness of fungicidal drugs.

\section{Results and discussions}

Table 1 shows the results of the fungicidal activity of plant extracts in relation to two isolated pathogens of grapes. The effectiveness of plant extracts against the two presented types of fungi is low. All types of Centaurea L. and the Siberian carpet cypress did not show antimycotic activity in all studied concentrations.

Extracts of marsh cudweed, dwarf everlast exhibited moderate antifungal activity at concentrations of $0.125 \%$. The highest fungistatic activity among the studied plant extracts was found in a case of common juniper - for culture V2 MIC was $0.0625 \%$.

Table 1. Fungicidal effect of plant extracts against two types of fungi isolated from grape leaves.

\begin{tabular}{|c|c|c|c|c|c|}
\hline \multirow{2}{*}{ Extracts } & \multirow{2}{*}{$\begin{array}{c}\text { Initial } \\
\text { concentration, } \%\end{array}$} & \multicolumn{2}{|c|}{ V1 } & \multicolumn{2}{c|}{ V2 } \\
\cline { 3 - 6 } & 1 & 0,125 & 0,25 & 0,125 & $>0,25$ \\
\hline \begin{tabular}{c} 
Gnaphalium uliginosum L. \\
\cline { 3 - 6 }
\end{tabular} & 1 & 0,125 & $>0,25$ & 0,125 & 0,25 \\
\hline $\begin{array}{c}\text { Helichrysum arenarium } \\
\text { (L.) Moench }\end{array}$ & 1 & $>0,25$ & - & $>0,25$ & - \\
\hline $\begin{array}{c}\text { Microbiota decussata } \\
\text { Kom. }\end{array}$ & 1 & $>0,25$ & - & $>0,25$ & - \\
\hline $\begin{array}{c}\text { Centaurea macrocephala } \\
\text { Muss.Puschk. Ex Willd. }\end{array}$ & 1 & & & & MFC, \% \\
\hline
\end{tabular}




\begin{tabular}{|c|c|c|c|c|c|}
\hline Centaurea montana L. & 1 & $>0,25$ & - & $>0,25$ & - \\
\hline Centaurea dealbata Willd. & 1 & $>0,25$ & - & $>0,25$ & - \\
\hline Juniperus communis L. & 1 & 0,125 & 0,25 & 0,0625 & $>0,25$ \\
\hline
\end{tabular}

Table 2 shows the results of the fungicidal activity of industrial fungicides containing known active substances. The best results were found for the drug Maxim, with the active substance fludioxonyl. MIC for two types of fungi was equal to $0.097 \mu \mathrm{g} / \mathrm{mL}$, but the fungicidal concentration was slightly higher in the case of V1 and amounted to 3.125 $\mu \mathrm{g} / \mathrm{mL}$, for $\mathrm{V} 2-12.5 \mu \mathrm{g} / \mathrm{mL}$. According to the literature data, fludioxonyl (an analogue of natural antimycotic substances) is a broad-spectrum fungicide that inhibits the growth of mycelium. The substance has a long-term protective and weak systemic effect, suppresses glucose phosphorylation during cellular respiration. Its influence on the growth of mycelium, the reproduction of the pathogen and the formation of cell membranes is associated with a violation of the function of cell membranes [21]. Less high results were shown by the drug Karamba with the active substance metconazole. It should also be noted that the fungi in case V1 turned out to be slightly more sensitive, unlike V2: MIC was 3.75 and $7.5 \mu \mathrm{g} / \mathrm{mL}$ for $\mathrm{V} 1$ and $\mathrm{V} 2$, respectively, and the values of the MFC for the first fungi was $30 \mu \mathrm{g} / \mathrm{mL}$, whereas for the second - twice as much. Metconazole is a systemic fungicide of the chemical class of triazoles, has a long-term therapeutic and protective effect. It acts both proactively and when signs of the disease have already appeared, stopping the development of the infection that has begun. The mechanism of action of metconazole is to inhibit the biosynthesis of ergosterol, a violation of the biosynthesis of the cell membranes of the fungi [22]. Also, the values of MFC $(20 / 1,25 \mu \mathrm{g} / \mathrm{mL})$ were established for drug "RidomilGold MZ-profi" - with active substances mankoceb / mefenoxam. Mankoceb is a contact fungicide of protective action, when dissolved in water it forms ethylene bisisothiocyanate sulfide, which under the action of ultraviolet light is converted into ethylene bisisothiocyanate. Both substances affect the enzyme systems of fungi that contain sulfhydryl groups. They disrupt about six important biochemical processes in the mitochondria and cytoplasm of fungal cells and do not inhibit the biosynthesis of citrate in spores [23]. Mephenoxam inhibits the formation of proteins in fungi, suppresses the synthesis of ribosomal RNA [24]. Preparations of the chemical class of triazoles of the triazole class "Premis 200", "Phytolecary", "Universal", "Skor" had sufficiently high inhibitory concentrations in the range of $15.625-62.5 \mu \mathrm{g} / \mathrm{mL}$, however, they did not cause complete death of the fungi and thus MFC were not detected at the studied concentrations. The least activity was found in a case of "Strobi" and "Abiga Peak". Both types of fungi proved to be resistant to these industrial fungicides.

Table 2. Fungicidal effects of industrial fungicides.

\begin{tabular}{|c|c|c|c|c|c|}
\hline \multirow{2}{*}{$\begin{array}{l}\text { Type of } \\
\text { industrial } \\
\text { fungicide }\end{array}$} & \multirow{2}{*}{$\begin{array}{c}\text { Initial } \\
\text { concentration, \% }\end{array}$} & \multicolumn{2}{|c|}{ V1 } & \multicolumn{2}{|c|}{ V2 } \\
\hline & & $\begin{array}{l}\mathrm{MIC}, \\
\mu \mathrm{g} / \mathrm{mL}\end{array}$ & $\begin{array}{l}\mathrm{MFC}, \\
\mu \mathrm{g} / \mathrm{mL}\end{array}$ & $\begin{array}{c}\mathrm{MIC}, \\
\mu \mathrm{g} / \mathrm{mL}\end{array}$ & $\begin{array}{l}\mathrm{MFC}, \\
\mu \mathrm{g} / \mathrm{mL}\end{array}$ \\
\hline Maxim & 0,01 & 0,097 & 3,125 & 0,097 & 12,5 \\
\hline Karamba & 0,024 & 3,75 & 30 & 7,5 & $>60$ \\
\hline
\end{tabular}




\begin{tabular}{|c|c|c|c|c|c|}
\hline Premis 200 & 0,04 & 50 & $>500$ & 100 & $>500$ \\
\hline Fitolekar & 0,05 & 62,5 & $>500$ & 62,5 & $>500$ \\
\hline Universal & 0,1 & 15,6 & 250 & 62,5 & 125 \\
\hline Skor & $0,1 \%$ & 15,625 & $>500$ & 7,81 & $>500$ \\
\hline Strobi & $0,1 \%$ & $>250$ & - & $>250$ & $>500$ \\
\hline $\begin{array}{c}\text { RidomilGold } \\
\text { MZ-profi }\end{array}$ & $0,1 \%$ & $20 / 1,25$ & $20 / 1,25$ & $10 / 0,625$ & $20 / 1,25$ \\
\hline \begin{tabular}{c} 
Abiga-Peak \\
\hline
\end{tabular} & $0,1 \%$ & $>500$ & - & 500 & $>500$ \\
\hline
\end{tabular}

\section{Conclusions}

Ethanol extracts of plants have proved ineffective against fungal pathogens of grapes and had rather low inhibitory activity, without causing the death of fungal cells. The studied industrial fungicides have showed high results of activity, the samples "Maxim", "Karamba" and "RidomilGold MZ-profi" showed the highest indicators of MIC and MFC. The isolated native fungi were resistant to the "Abiga Peak" and "Strobi". Thus, it is possible to note the most active substances for of isolated native fungi that inhibited their growth and caused death at sufficiently low concentrations: fludioxonyl, metconazole and mancoceb/mefenoxam.

\section{References}

1. OIV, International Organisation of Vine and Wine. Statistiical Report on World Vitiviniculture. 2019. Available online: http://oiv.int/public/medias/6782/oiv-2019statistical-report-on-world-vitiviniculture.pdf (accessed on 15 November 2020)

2. G.F.L. Pascoal, M.A. Cruz, J.P. Abreu, M.C.B. Santos, G.B. Fanaro, M.R. M. Júnior, O.F. Silva, R.F.A. Moreira, L.C. Cameron, M.S.L. Ferreira, A.J.Teodoro, Food Chem., 366, 130644 (2022)

3. J.H. Kim, Q. Wang, J.M. Choi, S. Lee, E.J. Cho, Nutr. Res. Pract., 9, 5 (2015)

4. F.M.L. Cavalcante, I.V. Almeida, E. Düsman, M.S. Mantovani, V.E.P. Vicentini Drug Chem. Toxicol., 41 (2018)

5. L. Marabini, G. Melzi, F. Lolli, M. Dell'Agli, S. Piazza, E. Sangiovanni, M. Marinovich, J. Photochem. Photobiol. B., 204 (2020)

6. M. Anđelković, B. Radovanović, A. M. Anđelković, V. Radovanović, Foods Hum.Nutr. 70 (2015)

7. R.M. González-Rodríguez, B. Cancho-Grande, J. Simal-Gándara, Food Chem., 125 (2011)

8. R.B. Ferreira, S.S. Monteiro, M. An. Piçarra-Pereira, A.R. Teixeira, Trends in Biotechnology, 22, 4 (2004)

9. A.Y. Tetteh, T.C. Wehner, A.R. Davis, Crop Sci. 50 (2010) 
10. A.R. Davis; A. Levi; A. Tetteh; T.C. Wehner, V.M. Russo, M. Pitrat., J. Am. Soc. Hort. Sci. 132 (2007)

11. A. Pérez-García, D. Romero, D. Fernández-Ortuño, F. López-Ruiz, A. De Vicente; J.A. Torés, Mol. Plant Pathol. 10 (2009)

12. P. LeRoux, and M. Clerjeau, Crop Prot. 4, 137-160 (1985)

13. G. Miller, Sustaining the earth, Pacific Grove, 9, 6 (CA: Thompson Learning, Inc. 2005)

14. D. Romero, A. de Vicente; H. Zeriouh; F.M. Cazorla; D. Fernández-Ortuño; J.A. Torés; A. Pérez-García, Plant Pathol. 56, 976-986 (2007)

15. N. Sharonova, E. Nikitin, D. Terenzhev, A. Lyubina, S. Amerhanova, K. Bushmeleva, A. Rakhmaeva, I. Fitsev, K. Sinyashin, Plants, 10, 7 (2021)

16. D. Terenzhev, N. Sharonova, A. Ermakova, S. Gumerova, K. Bushmeleva, G. Shumatbaev, I. Fitsev, A.S. Ponomareva, Asian J. Chem., 31,12 (2019)

17. S.K. Gumerova, A.P. Lyubina, I.M. Fitsev, T.G. Belov, N.L. Sharonova, D.A. Terenzhev, K.N. Bushmeleva, Asian J. Chem., 31, 11 (2019)

18. A. Marsoul, M. Ijjaali, I. Oumous, B. Bennani, A. Boukir, Materials Today: Proceedings, 31,1 (2020)

19. A.M. Rakhmaeva, S. M. Gumerova, D. A. Terenzhev, N. L. Sharonova, I. M. Fitsev, Bulletin of Kazan State University, 3,5

20. Clinicaland Laboratory Standards Institutes (CLSI), Reference Method for Broth Dilution Antifungal Susceptibility Testing of Yeasts. CLSI standard M27, 31 (Wayne, Pennsylvania, USA, 2017)

21. K. Bersching, S. Jacob, J Fungi (Basel) 7, 5 (2021)

22. T. A. Unger, Pesticide Synthesis Handbook (William Andrew Publ., 1996)

23. M. Thiruchelvam, Encyclopedia of Toxicology (Second Edition) (2005)

24. G. Parra, J.B. Ristaino, Plant Dis. 85 (2001) 